\title{
DAMPAK PENDIDIKAN DAN STATUS BEKERJA IBU TERHADAP PENGAMBILAN KEPUTUSAN PRASEKOLAH ANAK DI JAWA BARAT
}

\author{
Nenny Hendajany ${ }^{1 *}$, Deden Rizal Riyadi ${ }^{1}$, Ae Suaesih ${ }^{1}$ \\ ${ }^{1}$ Universitas Sangga Buana, Indonesia \\ *e-mail: nennyhendajany@gmail.com
}

\begin{abstract}
Abstrak
Tujuan dari penelitian ini adalah untuk mengetahui adakah dampak pendidikan ibu serta status ibu bekerja terhadap pengambilan keputusan menyekolahkan anak di usia dini. Data yang digunakan adalah data SUSENAS Jawa Barat tahun 2018. Metode yang digunakan adalah analisis probabilitas logit dan probit. Pendidikan ibu berdasarkan jenjang terakhir yang dimiliki merupakan variabel independen, dan status ibu bekerja sebagai dummy variable. Hasilnya menunjukkan bahwa pendidikan ibu yang lebih tinggi cenderung memperbesar peluang seorang anak mengikuti prasekolah dibandingkan ibu yang pendidikan SD ke bawah. Begitu pula status ibu bekerja cenderung memperbesar peluang anak mengikuti prasekolah dibandingkan ibu yang tidak bekerja.
\end{abstract}

Kata kunci: Prasekolah; Pendidikan Usia Dini; Status Ibu Bekerja; Pendidikan Ibu

\begin{abstract}
The purpose of this study was to determine whether there is an impact of maternal education and the status of working mothers on decision-making to send their children to school at an early age-the data used in West Java SUSENAS data in 2018. The method used is logit and probit probability analysis. Mother's education based on the last level owned is an independent variable and the status of working mothers as a dummy variable. The results show that mothers with higher education tend to increase the chances of attending preschool compared to mothers with lower elementary education. Likewise, the status of working mothers tends to increase the chances of children attending preschool compared to mothers who do not work.
\end{abstract}

Keywords: Preschool; Early Childhood Education; Working Mother Status; Mother's Education

This is an open access article under the CC BY-SA license.

Copyright @ 2021 by Author. Published by Universitas Pendidikan Ganesha.

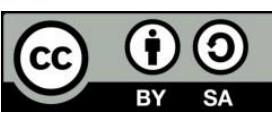

\section{PENDAHULUAN}

Masa kanak-kanak merupakan suatu tahapan masa yang sangat mempengaruhi manusia baik secara fisik maupun psikologis. Masa kanak-kanak sebagai pondasi kehidupan manusia di masa depan. Oleh karena itu pada masa kanak-kanak yang diisi dengan hal yang baik tentulah kelak ia akan menjadi manusia yang berkualitas. Pendidikan anak pada usia dini berpengaruh terhadap perkembangan dan outcome masa depan anak (Magnuson \& Duncan, 2016). 
Hasil penelitian menemukan bahwa otak manusia perkembangannya mempunyai batas waktu atau biasa disebut "windows of opportunity", berbeda dengan lukisan yang bisa diselesaikan kapan saja. Jendela peluang adalah periode ketika otak memerlukan jenis-jenis masukan tertentu untuk menciptakan atau menstabilkan struktur yang bertahan lama. Jendela peluang tersebut ada pada penglihatan, kemampuan linguistik, gerakan, perasaan, musik, matematika, logika dan sebagainya (Rahmat, 2005), sebagaimana terlihat pada Gambar 1.

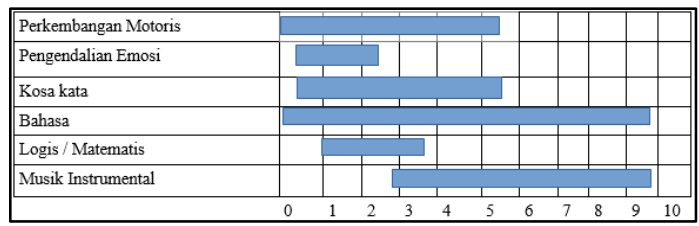

Gambar 1. Jendela Peluang Kecerdasan

Terlihat bahwa mayoritas kecerdasan akan berkembang pada masa emas (golden age) yaitu $0-6$ tahun. Namun otak (neonatal) atau kecerdasan ini masih bagaikan sebuah lukisan dalam bentuk sketsa, sebuah cetak biru yang belum sempurna. Tangan-tangan lingkungan sekitarnyalah yang akan menyelesaikannya atau menelantarkannya. Setiap anak masingmasing memiliki potensi berbagai kecerdasan atau kecerdasan bawaan. Setiap anak secara potensial pasti berbakat, tetapi ia mewujud dengan cara yang berbeda-beda (Dryden \& Jeanette, 2002).

Orang tua dan lingkunganlah yang bertanggung jawab untuk bisa mendidik dan mengoptimalkan kecerdasan anak baik secara intelektual, emosional, dan spiritual. Usia emas merupakan waktu terbaik bagi anak untuk mempelajari berbagai macam keterampilan, membentuk kebiasaan-kebiasaan yang akan berpengaruh pada masa kehidupan selanjutnya. Keterlibatan keluarga yang kuat dalam sistem dan program anak usia dini adalah pusat-bukan tambahan-untuk mempromosikan perkembangan intelektual, fisik, dan sosial-emosional anak yang sehat; mempersiapkan anak-anak untuk sekolah; dan mendukung pencapaian akademik di Sekolah Dasar dan seterusnya (Kelly, 2020).

Melalui PAUD (pendidikan usia dini) dapat membantu menstimulus dan mengoptimalkan berbagai potensi kecerdasan anak, baik yang bersifat formal maupun informal. Karena secara umum, tujuan pendidikan anak usia dini adalah mengembangkan potensi anak sejak dini sebagai persiapan untuk hidup dan dapat menyesuaikan diri dengan lingkungannya (Nurani S, 2013). Selain itu PAUD dapat memberikan rangsangan pendidikan untuk membantu pertumbuhan dan perkembangan jasmani dan rohani anak agar memiliki kesiapan dalam memasuki pendidikan lebih lanjut (Undang-Undang tentang Sistem Pendidikan Nasional, Bab I pasal 1 ayat 14).

Hasil penelitian menarik dari Delalibera \& Ferreira (2019) bahwa pendidikan usia dini mempengaruhi pertumbuhan ekonomi di masa depan. Mereka menggunakan data sekolah usia dini tahun 1996 di AS dengan mengkaitkan pertumbuhan ekonomi di tahun 2018, ternyata pendidikan usia dini dapat menjelaskan besaran peningkatannya. Hasil penelitiannya menyimpulkan bahwa realokasi

Jurnal IImu Sosial dan Humaniora | 476 
pengeluaran publik dari pendidikan formal ke pendidikan usia dini akan berdampak pada pendapatan per kapita dan produktivitas.

Gubernur Jawa Barat mempunyai komitmen dalam meningkatkan pendidikan dan partisipasi pada PAUD diantaranya melalui pembentukan Bunda PAUD pada 26 kabupaten/kota di Jawa Barat. Bunda PAUD hadir untuk memastikan bahwa kebijakan-kebijakan yang dibuat didaerah turut menyertakan dukungan untuk pembangunan pendidikan anak usia dini. Hal ini untuk mendorong peningkatan kualitas PAUD di Jawa Barat. Namun masyarakat Jawa Barat masih sedikit yang merasakan pelayanan PAUD, yaitu sekitar $11 \%$ (Solehudin, 2018).

Angka Partisipasi Kasar (APK) untuk PAUD Provinsi Jawa Barat tahun 2019 sebesar 27,67\% (PAUD dilingkungan Kemendikbud). Nilai APK PAUD sekitar 36,28\% (PAUD dilingkungan Kemendikbud dan Kemenag). Kondisi ini tentu saja memprihatikan, karena di bawah ratarata nasional sebesar $34,29 \%$ (PAUD Kemendikbud) dan 41,18\% (PAUD Kemendikbud-Kemenag) (Kemendikbud, 2020). Kecilnya nilai APK PAUD dikarenakan fasilitas pendidikan usia dini masih terbatas.

Fasilitas pendidikan pra sekolah lebih banyak disediakan oleh pihak swasta dibandingkan dengan pihak pemerintahan. Pengelola swasta sekitar 99\% sedangakan fasilitas yang disediakan pemerintah atau sekolah negeri kurang dari satu persen untuk setiap jenis sekolah usia dini. Hal ini terlihat dari jumlah sekolah yang disediakan di Jawa Barat berdasarkan kabupaten kota. Tentu saja penyediaan fasilitas oleh swasta ini berdampak pada pembiayaan yang ditanggung oleh orang tua siswa.

Yizengaw \& Tessega (2020) meneliti perbedaan sekolah negeri dan swasta untuk usia pra sekolah, melalui metode survei dengan analisis komparatif. Hasilnya menyatakan terdapat perbedaan implementasi dikedua jenis sekolah tersebut. Kedua jenis sekolah belum siap untuk mengimplentasikan kebijakan kurikulum sekolah usia dini yang ditetapkan pemerintahannya.

Orang tua sangat berperan dalam pendidikan anak-anak. Pendidikan orang tua pun sangat menentukan bagaimana pendidikan anak. Terdapat perbedaan kesiapan bersekolah anak antara orang tua yang berpendidikan tinggi dengan yang tidak (Sulistyaningsih, 2005). Pendidikan orang tua terutama ibu mempengaruhi keberhasilan akademik anak ketika remajanya (Breinholt \& Holm, 2020). Hasil penelitian GimenezNadal \& Molina (2013) menunjukkan bahwa pendidikan ibulah yang menentukan pendidikan anak pada usia dini.

Tanggung jawab pengasuhan anak terutama di Indonesia masih dominan menjadi kewajiban seorang ibu. Hal ini menjadi dilema bagi ibu yang berada dalam status bekerja di luar rumah, terdapat pilihan apakah akan terus bekerja atau memutuskan untuk berhenti (McRae, 2003). Menurut Hakim (2002) prefensi gaya hidup merupakan penentu utama pilihan pekerjaan, pola kerja dan keluarga. Sementara saat ini, kecenderungan ibu bekerja di luar rumah terutama Indonesia cukup tinggi.

Jurnal IImu Sosial dan Humaniora | 477 
Jumlah pekerja perempuan di Jawa Barat semakin lama semakin meningkat baik dari nilai absolut maupun nilai relatifnya. Data BPS (2019) pada Tabel 1 memperlihatkan bahwa ada peningkatan persentasi partisipasi perempuan dalam angkatan kerja, dimana tahun 2016 sekitar $34,6 \%$ dan tahun 2018 sekitar $36,8 \%$. Pekerja perempuan pada umumnya beralasan bekerja untuk meringankan beban ekonomi keluarga (Dewi, 2012). Bekerjanya seorang perempuan selain untuk membantu keuangan keluarga juga untuk aktualisasi dirinya.

Keadaan ibu bekerja tentu saja mempengaruhi kuantitas komunikasi antara ibu dan anak, namun kondisi ibu bekerja ternyata dapat meningkatkan kemandirian anak (Geofanny, 2016). Perkembangan anak usia 5-6 tahun untuk ibu bekerja berkembang secara baik dengan memilih peran ibu pendamping bagi anak (Filtri, 2017).

Tabel 1. Persentase Pekerja Wanita di Jawa Barat

\begin{tabular}{ccrc}
\hline \multirow{2}{*}{ Tahun } & \multicolumn{3}{c}{ Tenaga Kerja } \\
\cline { 2 - 4 } & Laki-laki & Perempuan & Total \\
\hline 2016 & 13.256 .194 & 7.020 .918 & 20.277 .112 \\
2017 & 13.340 .688 & 7.381 .650 & 20.722 .338 \\
2018 & 13.222 .934 & 7.693 .523 & 20.916 .457 \\
\hline Sumber: (BPS, 2019) & &
\end{tabular}

Keputusan orang tua dalam pendidikan anak sangat ditentukan oleh keadaan orang tuanya, terlebih keadaan seorang ibu yang secara tanggungjawab lebih besar dalam pendidikan anak. Keadaan ibu dapat dilihat dari tingkat pendidikannya. Selain itu waktu ibu di luar rumah akan mempengaruhi keputusan orang tua dalam pendidikan anaknya.

Penelitian terkait pendidikan ibu banyak mengarah pada outcome dan kesehatan anak kemudian hari. Hasil penelitian bahwa pendidikan ibu mempengaruhi tumbuh kembang dan outcome anak (Anderson \& Minke, 2007; Cui et al., 2019), mempengaruhi kesehatan anak (Martinson \& Choi, 2019; Rahman et al., 2008). Pada penelitian ini, pendidikan ibu dikaitkan pada keputusan orang tua menyekolahkan anak di usia dini dan mengkaitkan dengan status ibu yang bekerja di luar rumah.

Tujuan penulisan ini untuk mengetahui dampak dari pendidikan ibu dan status bekerja seorang ibu pada keputusan menyekolahkan anak di usia dini. Pendidikan ibu yang tinggi cenderung memperhatikan pendidikan anaknya, sehingga memungkinkan untuk menyekolahkan anak di usia dini. Begitupula status ibu bekerja memiliki waktu di rumah yang tidak terlalu banyak, sehingga lebih memilih anak bersekolah di usia dini.

\section{METODE}

Data yang digunakan adalah data Survei Sosial Ekonomi Nasional (SUSENAS) 2018. SUSENAS merupakan data mikro yang dikumpulkan 
oleh Badan Pusat Statistik. SUSENAS dilaksanakan setiap tahun untuk memberikan gambaran kemajuan pembangunan daerah. Pengumpulan data SUSENAS di bidang sosial ekonomi ini dilakukan pada tingkat nasional, provinsi, dan kabupaten/kota. Indikatorindikator yang diperoleh dari data SUSENAS antara lain aspek sosial ekonomi seperti kependudukan, pendidikan, kesehatan, kemiskinan, dan lain sebagainya. Sampel SUSENAS tahun 2018 berjumlah sekitar 300.000 rumah tangga yang tersebar di seluruh Indonesia. Pada penelitian ini penulis hanya menggunakan data SUSENAS 2018 khusus Provinsi Jawa Barat.

Data Susenas Jawa Barat terdiri dari 83.071 responden yang berada dalam 23.603 rumah tangga. Data yang dikumpulkan oleh BPS menggunakan unit analisis rumah tangga. Penulis dalam artikel ini mengambil responden anak-abak. Usia responden dibatasi antara satu sampai 10 tahun pada tahun 2018. Hasil screening data menghasilkan jumlah responden seluruhnya sebanyak 14.670 anak.

Penelitian ini melibatkan variabel dependen dan independent, dimana variabel dependen adalah keputusan pra sekolah anak dengan pengukuran dummy variable. Nilai satu untuk anak yang mengikuti prasekolah dan nol untuk anak yang tidak mengikuti prasekolah. Sedangkan variabel independen terdiri dari pendidikan ibu, status kerja ibu, umur ibu, umur ayah, tempat tinggal, sibling, dan jenis kelamin (pria=1). Variabel sibling merupakan variabel jumlah saudara kandung.

Peneliti membuat variabel-variabel tersebut dari data SUSENAS yang sesuai dengan kriteria. Sofware yang digunakan untuk menganalisis data yaitu STATA.

Kemungkinan ada dampak bias karena perbedaan kebijakan daerah kabupaten dan kota. Oleh karena itu, peneliti perlu menambahkan variabel kontrol. Peneliti menggunakan variabel kabupaten/kota yang menunjukkan tempat tinggal anak sebagai variabel kontrol. Pengontrolan kabupaten/kota dilakukan agar dampak dari perbedaan lokasi tempat tinggal dapat diminimalisir.

\section{Model Keputusan Prasekolah Anak}

Model keputusan anak bersekolah di usia dini dipengaruhi oleh pendidikan ibu, status ibu bekerja, usia orang tua, tempat tinggal dan jumlah anak dalam satu keluarga. Model dikontrol dengan variabel kabupaten/kota untuk mengurangi adanya bias lokasi tempat tinggal. Secara umum model dapat dituliskan dalam persamaan berikut:

PraSek $_{i}=\beta_{0}+\beta_{1}$ Ibu_SMP $_{i}+$ $\beta_{2} I b u \_S M A_{i}+\beta_{3} I b u_{-} P T_{i}+$ $\beta_{4}$ Ibukerja $_{i}+\beta_{5}$ UsiaIbu $_{i}+$ $\beta_{6}$ UsiaAyah $_{i}+\beta_{7}$ kota $_{i}+\beta_{8}$ Sibling $_{i}+$ $+\beta_{9}$ Pria $+\delta \boldsymbol{X}+\boldsymbol{\varepsilon}$

Metode Ordinary Least Square (OLS) untuk menyelesaikan model di atas memungkinkan nilai variabel dependen di luar 0 sampai 1. Oleh karena itu penulis menyelesaikan model persamaan (1) dengan probit dan logit untuk menghindari hal tersebut. Pada eksekusi model, peneliti membandingkan hasil dari OLS, Probit dan Logit. 
Penggunaan data mikro yang cukup besar (14.670 anak) diasumsikan bahwa data mengikuti distribusi normal, sehingga asumsi klasik diasumsikan terpenuhi. Pengujian asumsi klasik lainnya dilakukan seperti uji homoskedastisitas dan uji mulitikolinieritas. Diharapkan antar variabel independen tidak ada hubungan yang kuat satu sama lain, sehingga dapat dikategorikan saling independen.

\section{HASIL DAN PEMBAHASAN}

Responden yang memenuhi persyaratan usia sebanyak 14.670 anak. Penyebaran responden berdasarkan kabupaten/kota dapat di lihat dalam Tabel 2. Responden terbanyak dari Kabupaten Bogor sekitar 858 anak atau $5,85 \%$, sedangkan terkecil dari Kota Banjar sebanyak 270 anak atau $1,84 \%$. Hal ini sesuai dengan jumlah penduduk terbesar pada tahun 2019 ada di Kabupaten Bogor sekitar 5.965.410 jiwa dan terkecil di Kota Banjar sekitar 183.110 jiwa (BPS Provinsi Jawa Barat, 2021).

Keikutsertaan respon dalam PAUD berdasarkan pendidikan ibu diperlihatkan dalam Tabel 3. Jumlah responden yang mengikuti PAUD lebih kecil dibandingkan yang tidak, dimana ada 7.418 anak yang tidak mengikuti pendidikan usia dini dan 7.252 yang mengikuti pendidikan usia dini. Berdasarkan Tabel 3, pendidikan ibu terbagi menjadi 5 kategori yaitu Tidak Sekolah, Sekolah Dasar, Sekolah Menengah Pertama, Sekolah Menengah Atas, Diploma dan Sarjana, serta Pasca Sarjana. Anak dengan ibu berpendidikan Sekolah Dasar masih mendominasi yaitu sebesar 34,03\%, sedangkan paling rendah adalah anak dengan ibu berpendidikan Pasca Sarjana dengan $0,48 \%$.

Persentase anak yang mengikuti PAUD dilihat dari pendidikan ibunya, semakin tinggi pendidikan ibu maka persentase menyekolahkan anak di PAUD semakin besar. Ibu yang tidak sekolah memasukkan anaknya ke PAUD sekitar $42,61 \%$ sedangkan ibu dengan pendidikan Pasca Sarjana memasukkan anaknya ke PAUD sekitar $67,14 \%$. Pada Tabel 4 terlihat peningkatan persentase yang ikut PAUD dengan rata-rata peningkatan $4,9 \%$ untuk tiap naiknya tingkat pendidikan ibu. Hal ini sesuai dengan hipotesis peneliti, dimana pendidikan seorang ibu mempengaruhi secara positif keputusan pendidikan anak.

Kriteria responden berdasarkan tempat tinggalnya diperoleh sejumlah 4.920 responden tinggal di desa dan 9.750 responden tinggal di kota (Lihat Tabel 4). Ini menunjukkan bahwa kepadatan penduduk terjadi di kota. Responden yang tidak mengikuti PAUD lebih tinggi dibandingkan dengan yang ikut yaitu sebesar 50,6\% (7.418/14.670). Berdasarkan tempat tinggal responden maka peluang masyarakat kota mengikuti PAUD lebih tinggi dibandingkan masyarakat desa. Masyarakat kota yang mengikuti PAUD sebesar $52,5 \%$ sedangkan masyarakat desa hanya $43,3 \%$. Peluang responden yang tinggal di kota dan ikut PAUD sebesar 35\% (5.123/14.670). 
Tabel 2. Penyebaran Responden

\begin{tabular}{lcclcc}
\hline \multicolumn{1}{c}{ Nama } & \multicolumn{5}{c}{ Nama } \\
Kabupaten/kota & Frek. & $\%$ & Kabupaten/kota & Frek. & $\%$ \\
Bogor & 858 & 5.85 & Karawang & 648 & 4.42 \\
Sukabumi & 628 & 4.28 & Bekasi & 694 & 4.73 \\
Cianjur & 647 & 4.41 & Bandung Barat & 627 & 4.27 \\
Bandung & 810 & 5.52 & Pangandaran & 359 & 2.45 \\
Garut & 748 & 5.10 & Kota Bogor & 451 & 3.07 \\
Tasikmalaya & 541 & 3.69 & Kota Sukabumi & 369 & 2.52 \\
Ciamis & 529 & 3.61 & Kota Bandung & 523 & 3.57 \\
Kuningan & 452 & 3.08 & Kota Cirebon & 325 & 2.22 \\
Cirebon & 617 & 4.21 & Kota Bekasi & 616 & 4.20 \\
Majalengka & 486 & 3.31 & Kota Depok & 626 & 4.27 \\
Sumedang & 467 & 3.18 & Kota Cimahi & 401 & 2.73 \\
Indramayu & 557 & 3.80 & Kota Tasikmalaya & 453 & 3.09 \\
Subang & 511 & 3.48 & Kota Banjar & 270 & 1.84 \\
Purwakarta & 457 & 3.12 & & & \\
\hline
\end{tabular}

Tabel 3. Keikutsertaan Anak di Sekolah Dini dan Pendidikan Ibu

\begin{tabular}{|c|c|c|c|c|}
\hline \multirow{2}{*}{ Pendidikan Ibu } & \multicolumn{2}{|c|}{ Anak Ikut Paud } & \multirow{2}{*}{ Total } & \multirow{2}{*}{$\begin{array}{c}\text { Pesentase } \\
\text { Yang ikut PAUD }\end{array}$} \\
\hline & Tidak & lya & & \\
\hline Tidak sekolah & 1.227 & 911 & 2.138 & 42,61 \\
\hline SD & 2.716 & 2.276 & 4.992 & 45,59 \\
\hline SMP & 1.560 & 1.538 & 3.098 & 49,64 \\
\hline SMA & 1.438 & 1.841 & 3.279 & 56,15 \\
\hline Sarjana & 454 & 639 & 1.093 & 58,46 \\
\hline Pasca & 23 & 47 & 70 & 67,14 \\
\hline Total & 7.418 & 7.252 & 14.670 & \\
\hline
\end{tabular}

Tabel 4. Responden berdasarkan Tempat Tinggal dan Keikutsertaan PAUD

\begin{tabular}{|c|c|c|c|}
\hline \multirow[b]{2}{*}{ PAUD } & \multicolumn{2}{|c|}{ Tempat Tinggal } & \multirow[b]{2}{*}{ Total } \\
\hline & Desa & Kota & \\
\hline Tidak & 2.791 & 4.627 & 7.418 \\
\hline $\mathrm{Ya}$ & 2.129 & 5.123 & 7.252 \\
\hline Total & 4.920 & 9.750 & 14.670 \\
\hline
\end{tabular}


Karakteristik

responden

berdasarkan keikutsertaan PAUD dan jenis kelamin dapat dijelaskan dalam Tabel 5. Jumlah responden anak lakilaki sebanyak 52,15\%, sedangkan perempuan sebanyak 47,85\%. Berdasarkan Tabel 6, anak perempuan yang ikut PAUD di atas 50.6\% sedangkan anak laki-laki yang ikut
PAUD 48,4\%. Hal ini memperlihatkan minat pendidikan usia dini pada perempuan lebih tinggi dibandingkan anak laki-laki. Hal ini juga diperlihatkan dari APK PAUD tahun 2020, dimana APK laki-laki lebih kecil dibandingkan perempuan (BPS, 2021).

Tabel 5. Responden Berdasarkan Jenis Kelamin dan Keikutsertaan PAUD

\begin{tabular}{lccr}
\hline \multirow{2}{*}{ Jenis Kelamin } & \multicolumn{2}{c}{ Anak lkut Paud } & \\
\cline { 2 - 3 } & Tidak & lya & \multicolumn{1}{c}{ Total } \\
\hline perempuan & 3.468 & 3.552 & 7.020 \\
laki-laki & 3.950 & 3.700 & 7.650 \\
\hline Total & 7.418 & 7.252 & 14.670 \\
\hline \multicolumn{3}{c}{ Sumber: SUSENAS (2018), diolah }
\end{tabular}

Dalam perhitungan analisis, pendidikan yang dicapai ibu dengan pengukuran kategori dummy. Kategori dummy dibagi dalam empat kriteria, yaitu pendidikan ibu SD ke bawah, pendidikan ibu SMP, pendidikan lbu SMA, dan pendidikan ibu PT. Sehingga ada penggabungan pendidikan ibu tidak sekolah dengan pendidikan ibu SD, begitupula untuk pendidikan ibu sarjana dan pasca sarjana menjadi pendidikan ibu PT. Ibu yang berpendidikan di bawah sekolah dasar sebagai basis, dan pendidikan ibu SMP, SMA, dan PT sebagai kategori lainnya.

Model Persamaan (1) dieksekusi dengan tiga metode. Hasil estimasi ketiga metode tersebut ditampilkan dalam Tabel 6. Hasil ketiganya relatif sama untuk signifikansi semua variabel, kecuali pada nilai insersep. Koefisien intersep dengan metode OLS tidak signifikan sedangkan dengan metode Probit dan Logit keduanya sangat signifikan. Untuk Metode Logit nilai intersep negatif cukup besar dibandingkan dengan metode Probit, sehingga koefisien semua variabel dengan metode Logit cenderung memiliki nilai yang lebih tinggi dibandingkan hasil estimasi Probit.

Hasil dari dua model yaitu Probit dan Logit tidak begitu jauh berbeda dalam hal pengklasifikasian yang benar yaitu sekitar 59,98\%. Hasil kepekaan, kekhususan, dan nilai prediksi positif atau negatifnya cenderung sama antara model logit dan probit. Artinya penggunaan kedua model ini bisa digunakan dalam estimasi peluang seseorang anak bersekolah diusia dini. Perbedaan keduanya ada pada nilai intersep yang cukup signifikan berbeda. 
Tabel 6. Hasil Regresi, Probit dan Logit Keputusan Pra Sekolah Anak di Jawa Barat

\begin{tabular}{|c|c|c|c|}
\hline VARIABLES & $\begin{array}{l}\text { OLS } \\
\text { paud }\end{array}$ & $\begin{array}{l}\text { Probit } \\
\text { paud }\end{array}$ & $\begin{array}{l}\text { Logit } \\
\text { paud }\end{array}$ \\
\hline ibu_smp & $\begin{array}{c}0.0628^{* * *} \\
(0.0106)\end{array}$ & $\begin{array}{l}0.165^{\star * *} \\
(0.0278)\end{array}$ & $\begin{array}{l}0.268^{* * *} \\
(0.0450)\end{array}$ \\
\hline ibu_sma & $\begin{array}{c}0.0972^{* * *} \\
(0.0106)\end{array}$ & $\begin{array}{l}0.255^{\star \star \star} \\
(0.0278)\end{array}$ & $\begin{array}{l}0.412^{* \star *} \\
(0.0449)\end{array}$ \\
\hline ibu_pt & $\begin{array}{c}0.138^{\star *} \\
(0.0587)\end{array}$ & $\begin{array}{l}0.376^{\star \star} \\
(0.159)\end{array}$ & $\begin{array}{l}0.604^{\star \star} \\
(0.261)\end{array}$ \\
\hline ibukerja & $\begin{array}{l}0.0654^{* * *} \\
(0.00848)\end{array}$ & $\begin{array}{l}0.171^{* * *} \\
(0.0223)\end{array}$ & $\begin{array}{l}0.276^{\star * *} \\
(0.0359)\end{array}$ \\
\hline umuribu & $\begin{array}{l}0.0110^{\star * *} \\
(0.00101)\end{array}$ & $\begin{array}{l}0.0290^{\star * *} \\
(0.00267)\end{array}$ & $\begin{array}{l}0.0472^{* * *} \\
(0.00437)\end{array}$ \\
\hline umurayah & $\begin{array}{l}0.00350^{\star \star \star} \\
(0.000905)\end{array}$ & $\begin{array}{c}0.00917^{* * *} \\
(0.00238)\end{array}$ & $\begin{array}{l}0.0149^{* * *} \\
(0.00388)\end{array}$ \\
\hline kota & $\begin{array}{c}0.0538^{\star \star *} \\
(0.0101)\end{array}$ & $\begin{array}{l}0.142^{* * *} \\
(0.0266)\end{array}$ & $\begin{array}{l}0.229^{\star * *} \\
(0.0431)\end{array}$ \\
\hline sibling & $\begin{array}{l}-0.0281^{* * *} \\
(0.00417)\end{array}$ & $\begin{array}{c}-0.0742^{\star \star \star} \\
(0.0110)\end{array}$ & $\begin{array}{c}-0.121^{* \star *} \\
(0.0178)\end{array}$ \\
\hline pria & $\begin{array}{c}-0.0214^{\star * *} \\
(0.00804)\end{array}$ & $\begin{array}{c}-0.0568^{\star * *} \\
(0.0211)\end{array}$ & $\begin{array}{c}-0.0913^{* * *} \\
(0.0341)\end{array}$ \\
\hline Var Control & yes & yes & yes \\
\hline Constant & $\begin{array}{c}-0.00788 \\
(0.0349)\end{array}$ & $\begin{array}{c}-1.337^{\star * *} \\
(0.0926)\end{array}$ & $\begin{array}{c}-2.175^{\star * *} \\
(0.151)\end{array}$ \\
\hline $\begin{array}{l}\text { Observations } \\
\text { R-squared }\end{array}$ & $\begin{array}{c}14,670 \\
0.06\end{array}$ & 14,670 & 14,670 \\
\hline
\end{tabular}

Semakin tinggi pendidikan ibu memperlihatkan semakin besar peluang seorang anak di sekolahkan di usia dini. Terlihat dari koefisien dummy pendidikan ibu yang semakin tinggi semakin besar nilainya dibandingkan dengan pendidikan ibu SD ke bawah. $\mathrm{Hal}$ ini mendukung hasil penelitian sebelumnya dari Cui et al. (2019) dan dari Anderson \& Minke (2007).

lbu dengan status bekerja cenderung menyekolahkan anak lebih tinggi dibandingkan dengan ibu tidak bekerja. Kesibukan ibu di luar rumah membuat keputusan untuk menitipkan anaknya pada Lembaga Pendidikan sejak usia masih balita, sehingga peluang anak sekolah dini yang ibunya bekerja lebih besar dibandingkan ibu yang tidak bekerja. Hasil ini mendukung penelitian sebelumnya yang menyebutkan anak usia dini lebih mandiri pada ibu yang bekerja dibandingkan ibu tidak bekerja (Geofanny, 2016). Perkembangan emosianal anak usia dini dimana ibu bekerja lebih baik (Filtri, 2017). 
Hasil penting lainnya mengenai tempat tinggal anak, jumlah saudara kandung dalam satu keluarga, umur orang tua dan jenis kelamin anak semuanya signifikan. Variabel umur orang tua baik ibu dan ayah berpeluang meningkatkan peluang anak masuk PAUD. Semakin tinggi umur orang tua semakin memperbesar peluang anak masuk PAUD.

Hasil penelitian menunjukkan bahwa anak yang berada di kota lebih tinggi peluang memasukkan anak ke PAUD dibandingkan dengan anak yang di desa. Sedangkan jumlah saudara kandung terbukti menurunkan peluang seorang anak masuk PAUD, semakin banyak saudara kandung semakin kecil peluang anak masuk PAUD.

Anak berjenis kelamin laki-laki cenderung lebih kecil peluangnya masuk PAUD dibandingkan dengan anak perempuan. Hal ini terlihat dari koefisien variabel "pria" yang bertanda negatif.

\section{SIMPULAN DAN SARAN}

Semakin tinggi pendidikan ibu semakin besar peluang anak sekolah di usia dini. Pendidikan ibu tinggi memperlihatkan kepedulian akan perkembangan pendidikan anak dengan memanfaatkan usia emas dari anak. lbu yang bekerja mempunyai peluang lebih tinggi dalam menyekolahkan anaknya di usia dini dibandingkan dengan ibu yang tidak bekerja.

\section{UCAPAN TERIMAKASIH}

Peneliti mengucapkan terimakasih kepada Kemendikbud DIKTI yang telah membiayai penelitian tahun 2019-2020, sehingga data SUSENAS 2018 dapat kami olah menjadi sebuah artikel ini. Kepada Kampus USB yang mendukung atas pembuatan artikel ini. Kepada pihak LPPM yang juga mendukung peneliti dalam mengeluarkan karya publikasi secara rutin.

\section{DAFTAR PUSTAKA}

Anderson, K. J., \& Minke, K. M. (2007). Parent Involvement in Education: Toward an Understanding of Parents' Decision Making. The Journal of Educational Research, 100(5), 311-323. https://doi.org/10.3200/JOER.100 .5.311-323

BPS. (2021). Angka Partisipasi Kasar (APK) Anak Yang Mengikuti Pendidikan Anak Usia Dini (PAUD) Menurut Jenis Kelamin 2018-2020.

https://www.bps.go.id/indicator/28 /1441/1/angka-partisipasi-kasarapk-anak-yang-mengikutipendidikan-anak-usia-dini-paudmenurut-jenis-kelamin.html

BPS Provinsi Jawa Barat. (2021). Provinsi Jawa Barat Dalam Angka 2020.

Breinholt, A., \& Holm, A. (2020). Heterogeneous effects of less educated mothers' further education during early childhood on children's educational performance in adolescence. Research in Social Stratification and Mobility, 68, 100506. https://doi.org/10.1016/j.rssm.202 0.100506

Cui, Y., Liu, H., \& Zhao, L. (2019). Mother's education and child development: Evidence from the compulsory school reform in

Jurnal IImu Sosial dan Humaniora | 484 
China. Journal of Comparative Economics, 47(3), 669-692. https://doi.org/10.1016/j.jce.2019. 04.001

Delalibera, B. R., \& Ferreira, P. C. (2019). Early childhood education and economic growth. Journal of Economic Dynamics and Control, 98, 82-104. https://doi.org/10.1016/j.jedc.2018 .10 .002

Dewi, P. M. (2012). Partisipasi Tenaga Kerja Perempuan dalam Meningkatkan Pendapatan Keluarga. Jurnal Ekonomi Kuantitatif Terapan. https://ocs.unud.ac.id/index.php/j ekt/article/view/1906/1360

Dryden, G., \& Jeanette, V. (2002). Revolusi Belajar. Penerbit Kaifa.

Filtri, H. (2017). Perkembangan Emosional Anak Usia Dini Usia 5-

6 Tahun Ditinjau dari lbu yang Bekerja. PAUD Lectura: Jurnal Pendidikan Anak Usia Dini, 1(1), 32-38.

https://doi.org/10.31849/PAUDLE CTURA.V1I1.501

Geofanny, R. (2016). Perbedaan Kemandirian Anak Usia Dini Ditinjau Dari lbu Bekerja dan Ibu Tidak Bekerja. Psikoborneo: Jurnal IImiah Psikologi, 4(4), 464471. http://ejournals.unmul.ac.id/index.php/psi koneo/article/view/4230

Gimenez-Nadal, J. I., \& Molina, J. A. (2013). Parents' education as a determinant of educational childcare time. Journal of Population Economics, 26(2), 719-749.

https://doi.org/10.1007/s00148-
012-0443-7

Hakim, C. (2002). Lifestyle Preferences as Determinants of Women's Differentiated Labor Market Careers. Work and Occupations, 29(4), 428-459. https://doi.org/10.1177/07308884 02029004003

Kelly, M. (2020). Parents Play a Critical Role in Education. Thoughtco.

Kemendikbud. (2020). APK PAUD 2019/2020. Http://Publikasi.Data.Kemdikbud. Go.ld/.

Magnuson, K. A., \& Duncan, G. J. (2016). Can Early Childhood Interventions Decrease Inequality of Economic Opportunity? RSF: The Russell Sage Foundation Journal of the Social Sciences, 2(2), 123. https://doi.org/10.7758/rsf.2016.2. 2.05

Martinson, M. L., \& Choi, K. H. (2019). Low birth weight and childhood health: the role of maternal education. Annals of Epidemiology, 39, 39-45.e2. https://doi.org/10.1016/j.annepide m.2019.09.006

McRae, S. (2003). Constraints and Choices in Mothers' Employment careers: a Consideration of Hakim's Preference Theory. The British Journal of Sociology, 54(3), 317-338. https://doi.org/10.1111/j.14684446.2003.00317.x

Nurani S, Y. (2013). Konsep Dasar Pendidikan Anak Usia Dini. PT. Indeks.

Rahman, S. M. M., Subramanian, S. V, Houser, R., Liu, L., Ashworth, A.,

Jurnal IImu Sosial dan Humaniora | 485 
Tekeste, A., Semba, R. D., Pee, S. de, Sun, K., Sari, M., Akhter, N., \& Bloem, M. W. (2008). Effect of parental formal education on risk of child stunting in Indonesia and Bangladesh: a cross-sectional study. The Lancet, 371(9609), 322-328.

https://doi.org/10.1016/j.annrmp.2 005.04 .008

Rahmat, J. (2005). Belajar Cerdas. Penerbit MLC.

Solehudin, M. (2018). Baru 11 Persen Anak Usia Dini di Jabar yang Tersentuh PAUD. Detik.Com. https://news.detik.com/beritajawa-barat/d-4413398/baru-11persen-anak-usia-dini-di-jabaryang-tersentuh-paud

Sulistyaningsih, W. (2005). Kesiapan Bersekolah Ditinjau Dari Jenis Pendidikan Pra Sekolah Anak Dan Tingkat Pendidikan Orangtua. Psikologia, $1(1)$. http://repository.usu.ac.id/handle/ 123456789/15709?localeattribute $=$ en

Yizengaw, J. Y., \& Tessega, M. (2020). The implementation of early childhood care and education (ECCE) in Bahir Dar city administration: A comparative study between private and public pre-primary schools. Social Sciences \& Humanities Open, 2(1), 100013. https://doi.org/10.1016/j.ssaho.20 20.100013 